\title{
The Practices of Human Resource Management among Headmasters in Primary Schools: A Case Study of Selected National and Private Schools in Malaysia
}

\author{
Najla Aiman Mohamed Idrus, Azam Othman \& Ahmad Faizuddin”
}

\begin{abstract}
This study focused on the practices of human resource management among headmasters in primary schools across Malaysia. It concentrated on how headmasters perceive the concept of human resource management and translate it into practice. The qualitative research design was applied on six headmasters, four males and two females who served in selected national and private primary schools. Thematic analysis was used to catagorize the qualitative data into themes and sub-themes. The major findings of this study revealed that a majority of the headmasters perceived human resource management as a shared responsibility among teachers and school administrators while the headmaster is the key manager. Headmasters in national schools believed that human resource management is important to achieve educational goals. In contrast, a majority of headmasters in private schools believed that human resource management is important for sustainability. The study also revealed that the headmasters of national schools had less autonomy in decision-making as compared to headmasters of private schools. The results have implications on two major aspects; the leadership in human resource management and the system. The leadership implication will help headmasters identify the best practices of human resource management including support and professional development for the teachers. System refers to teacher placement and other aspects of policy implementation. Finally, this study recommends that more authority should be given to headmasters in managing human resources in schools, especially in the national schools.
\end{abstract}

Keywords: Human Resource Management, Leadership of Primary School Headmaster, Private \& National Schools

\section{Introduction}

The practice of human resource management has evolved in line with the society's economic needs and demands. Inevitably, the practice of human resource management at the school level is the key towards the school's success. A planned human resource management is important to ensure an effective school (Blanford, 2009). School leaders are expected to practise good human resource management to ensure the attainment of the schools' vision and mission. In conjunction with this, many agree that the role of school

\footnotetext{
${ }^{*}$ Kulliyyah of Education, International Islamic University Malaysia
} 
leaders is important in producing quality and dedicated teachers which has a strong correlation with students' success (Rusmini, 2004; Tim, Mike, Paul and Anne, 2009).

Obviously, the role of headmasters in the management and utilization of human resources is a complex task since the entire school is impacted by their decisions. As headmasters are the appointed leaders in a school community, they are responsible for handling the whole spectrum of human resource management at the school level. In general, this leadership responsibility includes but is not limited to supervising, mentoring, assessing and advocating. Nazrol (2000) indicates that a less effective school can transform into an effective one under the leadership of a quality headmaster.

The need to empower human resource management, however, arises at the stage of transforming initiatives into practice. The Master Plan for the Knowledge-Based Economy outlines 136 recommendations, of which 64 relates to human resource with almost half of that concerning education (Mohd Bakri, 2003). Whereby, in this current context, the introduction of the new National Educational Blueprint 2013-2025 proves our government's effort in making the practice of human resource management for the better. For instance, there are two components in the new National Educational Blueprint that gives weight to the practices and utilization of human resource management.

In Malaysia, the practice of human resource management in schools represents the utilization of the budget allocation by the stakeholder. In public schools, the stakeholder refers to the government while for the private schools the stakeholeder is the individual or organization that established the school. As reported in the media ("2015 budget speech", 2014) the Malaysian Prime Minister announced a huge budget amounting to RM800 million allocated for the educational sectors, particularly for the development and maintenance of schools across Malaysia. This shows the commitment of the Malaysian government towards accelerating educational excellence. Effective human resource management in schools is very crucial to avoid wasting such a huge budget.

Problems arise when people are appointed as headmasters in Malaysian national schools even though they are not competent to lead the school (Jamaliah \& Norashimah, 2005). As reported in the Malaysian Education Blueprint Summary (2013-2025), 55\% of principals across Malaysia receive no preparatory training before or during their first three years of promotion. This means that they maybe ill-prepared for their new roles. This is supported by Jamilah Ahmad \& Yusof (2011) who found that leadership training was given to the newly elected head of schools only after their appointments. Azlin Norhaini (2006) added that public school leaders lacked exposure to the leadership theories and did not adequately master the skills of school management. This leads to the failure of human resource management among headmasters due to their inability to distinguish between the highly important and less important tasks. Ahmad Zabidi (2005) mentioned that school leaders are facing management problems due to the lack of knowledge in management and the low moral and ethical values. These crises can be easily handled if headmasters know what to prioritize despite their challenging work demands.

In contrast, Siow et al. (1999) pointed out that headmasters in private schools are more popular as compared to those in the public schools. This might be due to their exemption from scrutiny by the Ministry of Education. Similarly, it was also reported that private schools had better problem-solving methods pertaining to matters that may affect human resources (A.Y. Abdulkareem, 2002). As a result, there has been a controversy on whether private schools are better than the public ones (Anyamkpa, 2000). 


\section{Human Resource Management}

There are many definitions given by different people in regards to the human resource management in the literature. In fact, the practice of human resource management has long existed and evolved. Legge (1989) opines that human resource management has undergone three phases of evolution: personnel management later moved to human resource management and to strategic human resource management. However, Malaysia, as a developing country is still in the phase of strengthening its human resource management. Clearly, it is crucial to determine the success of any organization regardless of its nature and goal. Shoeb (2011) states that anything, living or dead, for some specific reason, can be seen as a resource. This might include monetary, physical and human capital as part of the resources. He further defines that human resource management is a process that binds people and organization to accomplish both needs and purposes.

Generally, human resource management in an organization refers to the assets that need a systematic management to produce effective employees that will drive towards reaching organizational goal. The elements of human resource management include organizational analysis and development, personnel planning, training and staff performance, salary and remuneration, industrial relations, employees' welfare, internal organizational communication, discipline, information system and personnel record keeping and many more. Similarly, Cuming, (1980), Aina, (1982), Bratton and Gold, (1999) agree that human resource management involves recruitment, selection, maintenance, development, guidance and discipline of personnel by an organization. In addition, Omar (2001) states that human resource management comprises planning, security and health management, employee relation, benefit and remuneration. Meanwhile, Armstrong (2009) says that the Human Resource Management practice is viewed as a strategic approach to acquiring, developing, managing, motivating and gaining the commitment from employees who are seen as the organization's asset.

Zaidatol \& Foo Say Fooi (2007) agree that human resource management is a coordination and integration of human capital to move effectively towards achieving organization goal. Whereby, Amstrong (2010) defines human resource management as a strategic andcoherent approach to manage the most valuable organizationalassetwhich is the employees who individually and collectively contribute to the attainment of organizational objective and ensure the organizational survival in the competition.

Based on the literature above, human resource management is defined as two main forms: operational and strategic. Operational function refers to everyday activities such as checking employee attendance, punctuality, absenteeism, ensuring employee health and safety aspects as well as implementing laws and regulations. These operational functions are administrative and short-term oriented. Whereby, the strategic function is a long term planning that is more complex. It includes the decision making process, forecasting, and various development strategies. 


\section{Elements of Human Resource Management}

This study focuses on the practices of human resource management specifically on four major elements: acquiring, developing, rewarding and maintaining.

Acquiring: Gary (2010) defines acquiring as building an effective workforce with unique skills to enable the organization to meet its' strategic objectives, and prevent opponents from being successful.

Developing: Werner \& Desimone (2012) regard human resource development as systematic and planned activities by an organization aimed to provide its employees with the opportunity to learn necessary skills to meet current and future demands that will later on lead to organizational success. In the school context, Hewton (1998) describes that developing is one of the major influences to improve the quality of schools. According to him, fulfilling the individual needs of teachers within the school could enhance the quality of pupils. This is supported by Guskey \& Sparks (1996) who suggested that teacher professional development has the significant influence on student development and all other aspects of schools.

Rewarding: The literature includes salary increment as the most commonly used reward system by the human resource manager. Odden \& Kelly (2002) state that money is assumed as one motivator among many towards teacher performance. This is supported by Clincy (2003) who mentions that the reward system could increase productivity. Similarly, Harris \& Adams (2007) note that there should be an increase in financial incentives for teachers, for instance, the eligibility for pensions, holiday trip bonuses, etc., have also to be ruled in such a way that can distinguish induce teachers to stay until they reach the retirement age. However, some disagree as they see that the increase of salary would result in increased education expenses and may be politically difficult (Hoerr, 1998; Holt, 2001; Chamberlin et al., 2002). In fact, rewards can be tangible and intangible.

Maintaining: Herzberg (1966) in his motivation-hygiene theory emphasises on employee satisfaction. According to him, employees' satisfaction is strongly related to job attitude. This theory also explains how satisfaction can result in employees' being content with their job. Both motivation and hygiene factors listed by Herzberg that include recognition, advancement, possibility of growth, policy, interpersonal and intrapersonal relationships as well as job security are among the strategies used by employers to maintain or retain employees in the organization.

\section{Human Resource Management in Malaysian Primary Schools}

Human resource management in schools is not much different as compared to other organizations. In the school context, human resource includes teachers, students and the support staff. They need to be managed systematically to produce an effective school (Omardin, 1996). Hiring of effective teachers is one of the most important decisions that impacts student and school performance. Research shows that students under the guidance of ineffective teachers lag significantly behind students taught by effective teachers and this issue compounds over time (Darling-Hammond, 2000; Petersen, 2002; Rothman, 2005). Conversely, low-performing students with several effective teachers guiding them show positive improvement (Rothman, 2005; Sanders \& Rivers, 1996). 


\section{National Schools}

Ayob (2005) asserts that human resource management in public schools is less complicated especially in teacher and staff recruitment as it is executed under the responsibility of the Recruitment Division, Ministry of Education. Apart from that, any other matters related to the confirmation of service as well as teacher promotion are administered by the Human Resource Management Division under the Ministry of Education.

In Malaysia, the headmasters in the public primary schools are not involved with teacher recruitment and the selection process. The Education Service Commission (SPP) in collaboration with the Public Service Commission (SPA) undertake this task. In Malaysia, the teaching course is designed for the training of teacher candidates for both the primary and secondary schools. This program is offered at various teacher education institutes across the country. The duration of this course varies depending on the requirements of the respective courses offered. Courses offered for pre- service teaching include the following:

1) Postgraduate Teaching Course - One year: The requirements are Malaysian citizens who are physically and mentally healthy; not more than 35 years old; with a bachelor's degree or equivalent from a higher education institution (IPTA) or private educational institution (IPTS), local or overseas and having a degree that is recognized by the government of Malaysia.

2) B.Ed. (TESL) In-Service Twinning Program between the Ministry of Education Malaysia and local or overseas institutions (Six years: two years of Preparatory course and four years for the Bachelor's Degree).

3) B. Ed. Program - Five and a half years: One and a half year Preparatory course followed by four years for the B.Ed. Degree,

4) Program for Excellent Students at Overseas Universities - (Six years: One and a half years - two years of Preparatory Course, three years for the Bachelor's Degree, and one year for the Postgraduate Teaching Diploma Course).

For courses 2,3 and 4, the requirements are Malaysian citizen; physically and mentally healthy; not more than 20 years old; active in extra-curricular activities; having academic qualifications such as the Malaysian Certificate of Education (MCE) with a distinguished career in any of the three subjects and credits in three subjects (Malay, History, the other subjects as well) passed English; and meet the eligibility requirements for specific areas of study applied (Ministry of Education Malaysia, 2015). These courses entitle the holder to serve as Graduate Education Service Officers Grade DG41.

The administration of teacher training programs has two levels: the national and the state level. In some countries like Malaysia, the teacher training program is managed at the national level. However in other countries, it is managed at the state level. The administration by the national level means the program is highly scrutinized by the federal government. In short, every educational matter related to teacher training program will be determined by the federal government. This includes the type of programs as well as the requirements that potential teachers need to fulfil to gain their enrolment in this program.

All Malaysians with relevant qualifications are welcome to apply for the post of a teacher. An online application system is opened every February via the MOE website. Those shortlisted will be called to sit for a special examination to test their eligibility and passion in teaching and some other requirements. Subsequently, successful candidates will be interviewed by the School Management Division (SMD). Candidates will be enrolled for the teacher training program by the Teacher Education Division (TED) only after they 
have passed all stages of the selection process. TED is responsible for planning and implementing the teacher education programs. These programs are aimed at achieving the objectives of the National Education Philosophy and the Teacher Education Philosophy to produce competent, vibrant, good character, highly-intellectual, and technologically skilful teachers (Educational, Planning, and Research Division, 2015).

Upon their completion of the training program, teacher trainees will be placed in schools. The teacher placement system in Malaysia is controlled by the federal government at the national level (School Management Division 2011). Although the placement is done at the national level, teacher trainees are given options to choose up to three states for their placement. Nevertheless, the placement is subject to state needs (Educational Planning and Research Division, 2008). The district education office (DEO) or known as Pejabat Pendidikan Daerah will receive a list of names for teacher placements to the schools in that district. Official letter will be produced (School Management Division, 2011). A maximum of a three-probation period is given before they are confirmed into the service.

\section{Private Schools}

Unlike in public schools, headmasters in private primary schools have autonomy in the teacher recruitment and selection process. This could be regarded as a form of benefit to the headmasters in private schools as to some extent they have the freedom to choose potential teachers who will be working under their leadership. Having had the freedom of choice in the teacher recruitment is regarded as a chance to make a difference in student achievement and improve student learning (Seyfarth, 2005).

Private schools usually practice a comprehensive, web-based recruitment system which allows administrators and school boards to list and fill open teaching positions. This system assists schools in providing valuable services for potential candidates seeking employment. Listings of the openings and qualification requirements will be advertised online in the school website. Private schools can then do short listing from the pool of candidates that applied online. Alternatively, some private schools any job opening by other means like flyers or even outsourcing to recruitment companies like jobstreet.com. However, different schools may have different recruitment methods depending on the type of education service they provide. Nevertheless, they are placed under the scrutiny of the Private Education Division, Ministry of Education.

While many studies have been conducted about human resource management in Malaysian primary schools, most of them employed quantitative research methodology. Thus, it is the researcher's interest to add to current literature a qualitative research on this topic to add a new dimension to previous studies. Therefore, the objectives of this study are: (1) To explore how headmasters perceive the concept and practices of human resource management at the primary school level, (2) To examine the differences of human resource management practices in the private and national schools based on the following aspects: (a) Acquiring, (b) Developing, (c) Rewarding, and (d) Maintaining, and (3) To understand problems and dilemmas faced by headmasters in managing human resources. 


\section{Research Methodology}

The researcher opted to conduct this study qualitatively. Apart from that, a case study with phenomenological approach is used for data collection. As mentioned by Creswell (2005), a case study is an in-depth exploration of a specific entity (e.g. an activity, event, process or individuals) based on extensive data collection. In other occasion, he mentioned that it is based on constructivist, encouragement, or shared knowledge in which a researcher looks for meaning, contexts, and brings personal values into the study. It employs the use of subjective data, such as observations, interviews, open-ended questions, and journals (Creswell, 2003).

Merriam (1998:27) points out that "A qualitative case study is an intensive, holistic description and analysis of a single instance, phenomenon, or social unit". For this reason, the researcher adapts a case study as a method to study an entity which could be as small as one individual or as large as an entire school. Meanwhile, Sekaran \& Bougie (2010) describe case studies as detailed and conceptual analyses on similar issues in a number of different organizations but experienced the same nature and problems. On the other hand, Creswell (2003) defines it as a collective study where the researcher purposively selects multiple cases to exemplify one issue or concern to maximize different perspectives on the phenomenon studied. Similarly, Stake (2010) indicates that a case study concentrates on a research concern that belongs to a particular collection of cases categorically bounded by a common characteristic or condition.

\section{Participants and Setting}

Salkind (2009:89) defines sample as "a subset of the population". In other words, it refers to the number of participants needed for the research to represent the overall group of people studied. The researcher opted for a purposive sampling as it is believed to be sufficient for this research purpose which is to discover, understand and gain insight of what is studied (Merriam, 1998). Since generalization is not a goal for a qualitative research thus, a probabilistic sampling might not be necessary for this type of research (Merriam, 1998).

In purposive sampling, the researcher intentionally "selects individuals and sites to learn and understand the central phenomenon" (Creswell, 2005:218). As pointed out by Merriam (1998), the sample must be chosen based on certain criteria that meet the purpose of the study. For this reason, the researcher intentionally selects six respondents based on certain criteria that have been set. Criteria for respondents from national schools: (1) Have been in service for more than five years, and (2) Involved in both teaching and administrative tasks. Criteria for respondents from private schools: (1) Have been in service for more than five years, (2) Involved in both teaching and administrative tasks, (3) The school has been established for more than five years, and (4) The school gives a reasonably good impression to parents and community in terms of academic achievement and education service provided.

The participants of this study were selected from 7851 leaders or headmasters of public and private primary schools across Malaysia. Table 1 below shows the total number of headmasters across Malaysia based on the number of primary schools listed in the Ministry of Education Malaysia website (2015). Since there is only one headmaster in one school, 7851 represents the number of headmasters in primary schools across Malaysia. 
Table 1. Population of Study

\begin{tabular}{cc}
\hline \multicolumn{2}{c}{ Number of Primary Schools ( in 2013) 1} \\
\hline Type of Schools & Year 2013 \\
\hline Public Primary & 7,743 \\
Private Primary & 108 \\
\hline Total & $\mathbf{7 8 5 1}$
\end{tabular}

Source: Ministry of Education (2015)

Note: 1. Data as of 31 January 2015

Using purposive sampling, six respondents who meet the criteria were selected. Hence, three headmasters are selected from the national schools while another three from the private schools. Since this study applies a two-level interview, two respondents were teachers under the leadership of headmasters: one from the national primary school and another from a private primary school.

In addition to this, triangulation was also applied to confirm the validity of the responses given by the respondents. As highlighted by Slavin (2007), triangulation is important to support the presumption as it will avoid bias and to ensure the validity and reliability of the conclusions made. For this purpose, a two-level interview was conducted to support the responses given by the selected headmasters. Thus, apart from the six headmasters, an additional two teachers under the leadership of each headmaster were also interviewed. This practice is parallel to Biklen \& Bogdan (2007) who suggest that the researcher needs more than one source of information to enable them to establish a fact.

\section{Data Collection And Analysis}

\section{Semi Structured Interview}

Data were collected using semi-structured interviews to provide with the opportunity to explain their experiences. The researchers believed that semi-structured interviews were best suited to the nature of this study as they allowed the respondents to be more spontaneous but precise in giving answers. This is supported by Nik Suryani (2008) who pointed out that the respondents could feel more relaxed in describing the phenomenon using their own words rather than being restricted.

The researchers started the data analysis process by transcribing the audio recorded interview into narrative text. The transcription process was done very carefully in order to avoid summary, following Litchman (2006) who suggested that a researcher needs to transcribe the interview data by avoiding a summary. This was followed by coding process where data is broken down, conceptualized and grouped together in new ways (Strauss \& Corbin, 1998). In the coding process, Biklen \& Bogdan (2007) suggested to search for regularities that can be found in the data collected along with the patterns and the topic that the data cover. The second step in coding was to identify the sub-themes which refer to the detail or elaboration of the main idea. Here, the researchers were careful in giving 
judgment. For instance, the main point of respondent 1 was "a system to manage teachers to work in the same direction". Based on this main point, the researcher identified "to work in the same direction" as a sub-theme. Finally, themes were constructed. This was done by looking into the most repetitive main ideas given by respondents in the overall interview session. In this step, the researchers refered to the transcription and identified that 4 respondents who came out with relatively similar main ideas. These were "managing subordinate", "leading staff", "guiding subordinate" and "motivate subordinates". Based on the categorization of these main ideas, the researchers created a precise theme which is "systematic management".

\section{Findings and Discussion}

\section{The Concepts and Practices of Human Resource Management}

The concepts of human resource management held by headmasters revolved around the following themes: (1) Systematic management of teachers, (2) Managing school components, (3) Collective responsibility, (4) Accomplishment of educational goal, (5) Attainment of public confidence, and (6) Sustainability and competitiveness.

Regarding the systematic management of teachers, all six respondents agreed that human resource management is the systematic management of teachers as a school asset. For instance, respondent 1 said:

To me, human resource management at school is mainly about a system to manage the teachers. They are seen to me as a very important asset that can determine our students' excellence.

As for managing school components, four out of six respondents believed that human resource management includes the management of monetary resources and the school facilities. According to respondent 4:

As a headmaster, my duty is to manage every aspect of resources in this school. Although the main idea that I have pertaining to human resource management is about managing teachers, I believed other resources are my responsibility too. For example, financial management and facilities is very crucial for a smooth running of the school.

Moreover, two out of six respondents pointed out that human resource management is a collective responsibility, that is an effort to combine the skills, knowledge and efforts of teachers towards the attainment of educational goals. In relation to this, respondent 1 made the following comment: "It is merging the effort and skills of a group of people to reach organization goal."

Headmasters in national schools agreed that human resource management is important for the accomplishment of educational goals. Considering that the aim of national schools is to provide affordable and quality education to the public, their prime concern is to fulfil the National Education Blueprint. Due to that, national schools are under the scrutiny of the Ministry of Education. Concerning this matter, respondent 2 said:

I value human resource management as it helps me to direct every school member to have the same direction. As we are bound to the rules and 
regulations set up by the Ministry of Education, our final target is to reach the educational goal.

While six respondents agreed that the practice of human resource management is crucial at the school level, headmasters from private schools had different views on the importance of practising human resource management. Their views led to another theme that is attainment of public confidence. All three respondents from private school clearly mentioned this in their comments. For instance, respondent 4 claimed that: "Effective human resource management means good leadership. It will produce effective teachers and this will give positive impact to the students' achievements. This could increase public trust."

Another theme that emerged pertaining to the concept of human resource management is sustainability and competitiveness. In private schools, effective human resource management is seen as a mechanism to enable schools to be sustainable and competitive in the education market. Respondent 5 pointed out that: " To the public, a good school is the one that can provide great teachers, offer better facilities and produce good students. That is a bait to attract more student enrolment... and for us to sustain."

The findings show that most respondents in national schools believed that human resource management is important for the accomplishment of educational goals. They also agreed that the practice of human resource management is important for their schools. Respondents from the national schools stated the importance of human resource management as a mechanism to ensure quality education. This finding is consistent with Thomson \& Kleiner (2005) who asserted that human resource management is significant for quality education.

In contrast, the findings evidently show that a majority of the headmasters in private schools perceived the practice of human resource management as crucial for sustainability and competitiveness. This finding conforms with Gambini (2011) who found that the practice of human resource management in terms of staff development and mentoring can ensure the school's sustainability. Similarly, earlier research by Dyer (1985) also revealed that an effective human resource management is considered as a key factor to sustained performance and the survival of the organization.

\section{Differences between Headmasters of the National and Private Schools}

The differences between headmasters of national and private schools can be categorized into four specific elements of human resource management: acquiring, developing, rewarding and maintaining.

\section{Acquiring}

The interview question related to this element of human resource management sought to identify the differences in the perceptions of headmasters pertaining to the current teacher recruitment system at their respective schools. It aimed to explore their feelings and personal views towards the system. As a matter of fact, the recruitment of teachers for the national schools is done by the Ministry of Education under the Education Services Commission (SPP) while teacher recruitment for private schools is done internally. The findings are organized into four themes as follows: (1) Standardized systematic 
recruitment, (2) Bureaucratic hustle, (3) Highly qualified teachers, (4) Internal recruitment, and (5) Freedom of choice.

Regarding the first theme of standardized systematic recruitment, all three respondents from the national schools agreed that the current recruitment system by the Ministry of Education is standardized and systematic. Respondent 1 pointed out: "I am happy with the current recruitment system. Not only that it helps to ease the administrative workload, it only recruits those who are best fit for the position."

For the second theme about bureaucratic hassles, respondent 3 for instance, shared that:

The flaw that I mean is the bureaucratic hassle. Sometimes, under certain circumstances the school is in urgent need for a replacement teacher. However, due to many procedures that we have to follow it takes several months for that to settle. This is not good for the students.

All school leaders aim to select highly qualified teachers. This theme was highlighted by all three respondents from the public primary schools. All agreed that recruitment by SPP ensures qualified and well trained teachers. For instance, respondent 1 pointed out: "We have no doubt that teachers selected by SPP are well trained in their subject of specialization."

On the other hand, the following themes are resulted based on the interview findings with the respondents from the private schools. All three respondents from the private schools confirm that the teacher recruitment is done internally. Two out of three headmasters affirm that they have a direct involvement in the recruitment and selection process. Respondent 4 denoted that: "I am given the opportunity to involve directly in the teacher selection process along with other recruitment committees."

Another theme is freedom of choice. This is mentioned by respondent 4 who said: "It gives me freedom to choose the best candidate that suits my requirement to be part of the teaching personnel."

\section{Developing}

In terms of developing, six themes were generated from the interview data. They are listed as follows: (1) Enhancing teaching pedagogy, (2) Establishing the support system, (3) Strengthening psychological intelligence, (4) Intention to teach, (5) Motivate, and (6) Participating leadership.

All three respondents from the national schools highlighted that they give more effort in enhancing teaching pedagogy among teachers as a way to develop them. Respondent 1 mentioned that:

My biggest concern in this school is that... teachers are lacking in teaching pedagogy. It is a challenge for them to deal with students' behavior. Thus, I usually assign them to join any training related to the development of teaching pedagogy.

In contrast, headmasters in the private schools had different techniques for developing their subordinates. All three respondents from the private schools described 
their developing duties in a way that is categorized under one theme namely establishing a support system. Respondent 4 explained that: "I introduced a peer to peer support system as an effort to develop my subordinates. It works in a way that high performing teachers will guide under-performed teachers to reach a good KPI."

On the other hand, respondent 5 had a different approach to the support system. She described her practice as follows: "We organized an annual teacher retreat to any location outside the school...there, we have reflection, discussion and sharing moments on how to improve individual teacher's performance and other matters." that:

The third theme was strengthening psychological aspects. Respondent 2 explains

We are lucky to have many programs designed for teachers towards career enhancement and strengthening psychological aspect. This is to cope with the current challenges. For example, recently, we assign some of our teachers to the psychological intervention program organized by the Psychology and counseling unit of MOE.

Respondent 2 had a different view on how to develop his subordinates. According to him, teachers should always set their "niyyat" accordingly. This resulted to another theme namely intention to teach. He stated that: "I always remind my subordinates to set their "niyyat" accordingly. They should see it as "amanah" or responsibilities parallel to the actual teaching goal."

The most commonly highlighted point by all headmasters from the public and private schools was motivation. All six respondents mentioned that motivation is a method used to develop their subordinates. Respondent 1 asserted that: "I keep on giving motivation and advice to teachers under my leadership. I give my best support for them to develop mentally and in terms of their skill too."

\section{Rewarding}

In this context, the interview question mainly concentrates on the criterion that determines the likelihood to be rewarded as seen by the headmasters. Several themes are generated as follows: (1) Ability to promote innovation and creativity, (2) Commitment, (3) Leadership quality, (4) Student achievement, (5) Positivism, and (6) Key performance index.

The first theme was the ability to promote innovation and creativity. Four out of six respondents point this out as a key determinant in rewarding. Respondent 2 mentioned that: "I usually reward a teacher who is able to promote creativity amongst students. This could be measured through in-class or outside class activities where students have more rooms for self-expressions in their creativity."

The second theme was commitment. Four out of six respondents mentioned commitment as the determinant in rewarding. As highlighted by respondent 1: "I choose teachers with a high commitment and integration towards the school to be rewarded."

The third theme was leadership quality. This is pointed out by respondent 5 who affirmed that: "To me, teachers who are able to build and mould students" character are worth to be rewarded. Indeed, this is not a simple effort." 
The fourth theme was students' achievement. Four out of six respondents mentioned this in their comment. Respondent 3 for instance, said: "The first thing that I take into account is students' achievement. It measures how effective the teaching is."

The next theme was positivism. Two respondents mentioned this. From the interview session, it was understood that positivism is seen as important to both teacher and student. Respondent 1 stated that: "Positive trait is very important to me. Only positive teacher would be able to succeed. Thus... I take that into account too.

The most prominent point that resulted to another theme was the use of Key Performance Index. All six respondents highlight this in their response. Respondent 2 said: "I refer to the KPI. It includes most elements of the important to be an effective teacher."

In relation to this, there were four salient methods of rewarding commonly practiced by the respondents. They are classified under the following themes: (1) Recognition, (2) Salary increment, (3) Promotion, (4) Incentive, and (5) Idea sharing. In terms of recognition, respondent 1 mentioned that:

I do appreciate teachers internally...at school level. Apart from having recognition and awards, I do it by addressing teachers with the title that was given to them after their names. Such as "guru cemerlang". It is like a reward to them.

The other theme was salary increment. This is a well-known method of rewarding employees in any institution worldwide. Five out of six respondents highlighted this practice in their comments. Respondent 3 conveyed: "Here, salary increment seems to be the most favorable way to reward."

The third theme was promotion. It is captured in a statement made by respondent 4 who declared: "Promotion is another way that I use to reward my subordinates. Usually, we will promote the teacher that we identify as a high achiever to hold the higher office in this school." Next, the fourth theme was incentives. As mentioned by respondent 2:

Those who are awarded with "Anugerah Perkhidmatan Cemerlang" will be given a premium saving certificate of up to RM1000 during appreciation. This is organized and sponsored by the PPD, under the initiative of the Education Ministry.

The fifth theme is idea sharing. Respondent 1 mentioned: "Last year, I welcomed one of my best achiever (teacher) to share her teaching techniques and how she helps slow learners understand her subject better."

\section{Maintaining}

Three salient themes were generated as a result of the interview: (1) Practicing balanced workload distribution, (2) Maintaining good relationship, (3) Motivation, and (4) Democratic leadership.

The first theme was practicing balanced workload distribution. Respondent 2 disclosed that: 
One of my approaches to make them stay is by showing my empathy...I will not assign the same teacher to do things. This applies to extra classes, cocurricular activities, meetings and other commitments...we usually have a rotation system agreed by everyone.

The second theme was maintaining good relationship. From the interview, the researcher learnt that this practice is quite popular among headmasters. Four out of six respondents perceived that having a good relationship among school community will reduce their likelihood to move. Respondent 3 stated: "Another aspect that could hold a teacher from moving out is when she/he has affection towards the school."

The third theme was motivation. Respondent 5 and 6 agreed that motivating teachers could retain them longer in their school. Respondent 5 commented: "Having had an annual teacher retreat or any activities outside the school could be a gateway to the teachers. They seem to be more motivated and refreshed after a long working term."

The final theme generated for this research question was democratic leadership. Respondent 4 stressed that:

I make sure my teachers are happy by giving them more room to express their views and ideas about anything. It is like I practice the freedom of speech in this school so that teachers feel appreciated and needed. Two wise men are better than one. That's what I believe in.

From the foregoing analysis, in terms of practices, there were similarities and the differences in all four elements of human resource management highlighted in this study. In the acquiring process, headmasters from both the national and private schools agreed that only qualified candidates should be recruited as teachers. However, teacher acquisition in the national school is done externally by the Suruhanjaya Perkhidmatan Pelajaran (SPP) while the private school practices internal recruitment with direct participation by the headmasters.

The interview findings also disclosed that a majority of the headmasters would prefer to be involved in the recruitment process. Some also highlighted that they had less autonomy in the decision-making process as every decision that they make is bound to Ministry approval. A previous study by Chanhorm, Chotisukan and Gosalanantagon (2001) also confirms this finding. According to the study, school headmasters also have needs to participate in the school personnel administration which includes recruitment. Similarly, another research on public-private management differences by Williamson (2008) proved that national schools were more formalized and had less autonomy compared to the private schools.

Nevertheless, the findings also disclosed that internal acquisition or recruitment at the private school is seen favorable to the headmasters. All respondents from the private primary schools confirmed that they were involved in the teacher selection process. Although some declared that the final decision for teacher's recruitment is subject to the stakeholders' final decision, they agreed that their school practiced internal recruitment and allowed them to choose the best candidate most suited to the school interests. This matches the research findings of Tucker (2014) who administered a survey to principals in Miamion the level of discretion they had over the hiring of teachers at their school. The results show that the headmaster's decisions made at the school-level are important aspects of school effectiveness. 
In terms of the development process, headmasters in national and private schools agreed that they pay serious attention to this aspect of human resource management. Most commonly, the findings indicated that headmasters in both national and private schools put in a huge effort towards staff development through establishing the support system. Some respondents further clarified that they supported their subordinates by enrolling them for professional workshops. The current study is in agreement with a prior research by Rockoff (2004) who suggested that training can be a way for schools to control the quality of teachers by providing them with professional development opportunities or enrolling them for other programmes to develop their instructional skills. This is in agreement with the recommendation by Kinzy \& Minter (2008) who claimed that there should be workshops and professional programs where teachers of different skills and experiences can exchange their knowledge and experiences. These two-way interactions play a significant role to make teachers feel that they are growing professionally and in turn positively influences their productivity. However, it is learnt that different respondents initiate different types of support system depending on the needs, financial capabilities and other aspects.

In terms of reward, the majority of respondents stated that they rewarded high performing teachers with salary increment. This is supported by Odden \& Kelly (2002) who argued that money was assumed as one motivator among many towards teacher performance. In this case, the headmasters further described that salary increment was endorsed based on a standardized increment policy. This is parallel to Tomlinson (2000) who argued that performance-based reward can be a method to motivate people, and develop performance-focused teachers. In contrast, Ramirez (2001) disagreed. He criticized attempts to focus on monetary-rewards which, he believed can lead to increasing hatred towards the management, reducing employee loyalty that can result in a decrease in productivity.

In terms of maintaining the human resource, headmasters from both types of schools agreed that maintaining good relationships among school members and practicing democratic leadership would be a contributing factor in maintaining teachers. This is aligned with Shafritz, Ott, and Jang (2010) who claimed that a good relationship among staff can improve motivation, morale, and institutional success. Based on the data collected, more than half of the respondents agreed that a good relationship among the school community would reduce the likelihood of teachers leaving. Respondents further clarified that a good atmosphere, supportive colleagues and less pressure will create a conducive school environment that is just like home. The study is in agreement with Corral (2009) who recognized that the quality of relationship has direct implications on the work outcome.

\section{Problems Faced by Headmasters in Managing Human Resources}

Regarding the problems faced by headmasters in human resource management, they can be classified into ten themes as follows: (1) Leave issues, (2) Teaching pedagogy, (3) Turnover, (4) Management skill, (5) Lack of training, (6) Placement, (7) Work overload, (8) Scrutiny, (9) Positive traits, and (10) Ministry action.

The first theme was how staff utilize the annual and other leaves. Two out of six respondents identified this as a problem at their respective school. Respondent 1 
complained that: "Some of the teachers are not fit and are always on leave giving more workload to others. This is very frustrating. It is also not good for students."

The second theme was teaching pedagogy. This issue is commonly raised by respondents from national schools. Based on the interview, it is learnt that many young teachers were still lacking in terms of teaching pedagogy. As mentioned by respondent 2: "It is no doubt that they are all academically excellent. But many of them (young teachers) lack teaching pedagogy. It is hard for them to solve problems related to students' behaviour in the classroom."

In contrast, respondents from private school are concerned mostly on staff attrition and turnover. Two respondents from private schools indicated that low salaries is a demotivating factor to teachers that can cause them to move to either the government school or to another institutions for better pay. This is mentioned by respondent 4: "Good teachers have the tendency to move to a better school or join another industry. Some even join national school as they will have a better remuneration package."

Another theme was management skill. This is also seen as a barrier to the headmaster as some of them reveal that they lack management skill. Respondent 3 said: "Being a headmaster means I have to learn a lot of new things on top of my heavy workload. Ironically, I only received training few months after my appointment. So, it is more like a trial and error."

The fifth theme was work overload. Two respondents acknowledged that some teachers are not happy because they are overloaded with irrelevant job scope. Respondent 2 mentioned: "Some teachers are demotivated as they have to do some other irrelevant task over and over."

The sixth theme was scrutiny. Respondents claimed that government scrutiny can be an obstacle for them to play their roles as efficient headmasters. However, it was learnt from the interview that the degree of government scrutiny is different in the national and the private schools. Respondent 1 mentioned that: "It is quite hard for us to make a quick decision since everything is subject to the ministry's approval."

Similarly, respondent 4 revealed that:

Although we are in a private school, it does not mean that we have total authority or freedom to make decisions in our own school. For example, we have to follow textbooks and syllabus outlined by the Ministry of Education.

The seventh theme was the placement. This commonly happens in national schools as teacher placement is the prerogative of the Ministry of Education. Respondent 2 mentioned that:

I have to manage the transfer of teachers almost every year. This is very frustrating as some are very good teachers. Besides, changing teachers could stir the school target as I have to "tune" the newly transferred teacher to blend in with our school environment and work ethics.

Another theme was lack of training. Ironically, two out of three respondents from the national schools highlighted this matter. They said that this is one of dilemmas that can hinder their performance as headmasters. Respondent 1 mentioned that: 
I received formal training only after six months of my appointment. The training is more administrative rather than to manage my subordinates. That constitutes half a year of the schooling term. I feel burdened as everything is totally new to me.

In short, the findings in this section show that most headmasters complained about new teachers' lack teaching skills. This, according to them, is a serious problem. Berlier (2005) summarizes that an effective teacher should attain logical, psychological and good moral acts in teaching. This is also known as part of teaching pedagogy. Based on the interviews, a majority of the headmasters from the national schools highlighted that although newly elected teachers are highly educated in their subject of specialization, most of them are lacking in pedagogy skills. As a result, the teaching and learning process is less effective. They further clarified that the inefficiency in teaching takes place due to the actual classroom situation that does not match teachers' expectation. This finding agrees with Sabar (2004) and Scherff \& Hahs-Vaughn (2008) who ascertained that a common challenge of new teachers is to practice the pedagogy they have learned in the teacher training programs and to apply it in the real classroom setting. A study on pedagogical skills among teacher candidates by Johari \& Aslinda (2009) however, revealed the opposite. They found that pedagogical skills among the final year students at the Faculty of Education were very high.

This study also revealed that government scrutiny is one of the headmasters' dilemmas in managing their schools. This happens in both types of school - private and national under different circumstances. Respondents further revealed that they have limited decision-making authority as everything is subject to approval by the Ministry of Education. As a consequence, it is hard for them to make any decision for their school. This finding is consistent with a study by Wichenje, Simatwa, Ouom and Kegode (2012) on challenges of head teachers in Kenya that revealed government intervention as one of the challenges. Similarly, Mohd Bakri (2003) argued that in Malaysia, the Ministry of Education controls every detail of the curriculum and syllabus, programs, textbooks and even teacher promotion.

\section{Conclusions and Recommendations}

From the study, it is notable that all respondents understood the concept of human resource management. Most of them had a relatively general idea about their roles and the actual process to effectively manage the resource. They revealed that they lacked formal training and had to update their managerial knowledge from time to time due to changing policies. Ironically, some claimed their managerial practices were based on trial and error. Nevertheless, headmasters from national schools have positive reactions about the centralized recruitment of teachers done externally by the Education Service Commission (SPP) especially in relation to academic qualifications and subject specialization. Many of them perceived the current recruitment system as satisfactory and helpful. However, headmasters in the private primary schools were also content with the teacher selection process at their schools which is done internally. This is because most of them are directly involved in the process. This, they say gives them more freedom to choose teachers that best fit their respective institutions. In summary, all respondents, regardless of the school type, agreed that teacher recruitment is very important as teachers are the school's greatest asset. 
The present study reveals that the practice of human resource management by headmasters in national and private school is basically the same. It can be suggested that the practice of human resource management in terms of acquiring, developing, rewarding and maintaining human resources in both types of schools is headed towards the same final direction which is to reach the national education goal. However, certain aspects like the strategies and focus are relatively different. Apart from the differences in the teacher selection process, the difference can also be seen in the headmasters' view on how human resource management impacted their institutions. The interview results indicate that headmasters from national schools are enthusiastic in ensuring an effective human resource management which is in line with what has been outlined by the Ministry of Education. Their focus is to accomplish every policy and instruction by the ministry. On the other hand, headmasters of private schools see it differently. Their focus is for the sustainability and development of their business. Thus, their management style and decisions are made to benefit the stakeholder and institution and to gain more business. However, since the product of their business is still education and they strive to attain national educational goals and adhere to the policies of the Ministry of Education.

The implication of the practice of human resource management is seen as very important for school effectiveness. It can be said that it brings several implications towards the teacher, student and stakeholder, not just the school as a single learning institution. Based on interview results, a headmaster who understands the concept of human resource management will be able to identify diverse areas that require correctable actions or improvements. This leads to another implication which is teacher development which will also impact student achievement positively.

To sum up, the present study assumes that the practice of human resource management can be more effective if headmasters are well equipped with managerial knowledge and skills in line with the national education policy. The study also reveals that continuous support and training should take place due to the prevailing current education demands, challenges and policy changes. This will help the headmaster as the sole manager in school to be more committed, resourceful and capable in performing his/her job.

\section{Recommendations}

Based on the findings and interview sessions with respondents, the researcher would like to propose the following recommendations:

1) The Ministry of Education as the responsible body should be more aware of this issue. Guidance as well as continuous training are needed to prevent damaging effect to teachers, students and the other staffs in the school. This should be done concurrently with every policy change. Meanwhile, at the school level, headmasters should be open to feedback which can be gained from the subordinates through idea sharing.

2) Pertaining to work overload issue, the headmaster as the school manager can focus on essential matters that require immediate action rather than deal with other small issues. For example, through the interview sessions it is learnt that to increase student achievements, some headmasters believe that having extra daily classes is the solution. In reality, imposing extra classes outside school means giving more work to teachers. As a result, many teachers feel overburdened and stressed. In fact, the best way to improve student achievement is by having an effective teaching-learning process. 
3) Pertaining to teacher assessment, headmasters need to be more aware and careful in grading them. Though the grading process is very subjective, giving rewards to the right person should be the priority. Failure to do so may cause dissatisfaction among teachers which may lead them to think that the headmaster is biased and unfair to subordinates. This would tarnish intrapersonal relationships in the school.

4) In terms of management skill, headmasters who are worried that they lack the managerial capability should not delay to take action. Although the training organized by the Ministry of Education may be limited and tight to schedule, they need to grab opportunities given. Other options could include frequent discussions, sharing and asking for opinions from the experts.

5) One problem faced by headmasters in the national primary schools is the government scrutiny. During the interview, it is learnt that the decision making process is very timely as everything has to go through the Ministry of Education. Although suchgrievances by the headmasters could not alter the existing system or government policy in a blink, there are certain improvement measures that headmasters can take at the school level. For example, the headmaster is in control to make sure every document, support letter and procedures are completed as outlined by the ministry before sending them for approval. In most cases, completed documents will speed up the approval process. Other than that, being aware of datelines and doing frequent follow ups are other options. Alternatively, giving more autonomy to the headmasters to make decision on certain issues of management can be a more favorable choice.

Since this study has several delimitations, it is recommended that future researchers interested to study this topic should expand the scope of the study. A wider scope of human resource management expanded to a strategic human resource management is highly recommended.

\section{References}

Ahmad Zabidi Abdul Razak, (2005). Pembangunan Organisasi Pendidikan yang Cemerlang Berasaskan Ciri-Ciri Kepimpinan Islam [Development of excellent educational organization based on Islamic leadership characteristics]. Masalah Pendidikan, 28, 105-116.

Aina S., (1982). Personnel Management in Nigeria: A work-centred approach. Ikeja: Edition F. Communications.

Anyamkpa E.C. (2000). A comparative study of the management of public and private secondary schools in Amuwo-Odofin Local Area of Lagos State. Unpublished B.Ed. Project. University of Ilorin, Ilorin.

Armstrong, M., (2009). Armstrong's Handbook of Human Resource Management Practice. $11^{\text {th }}$ Edn., Kogan Page, USA.

Armstrong, M. (2010). Armstrong's Essential Human Resource Management Practice: A Guide to People Management. Kogan Page, USA.

AY Abdulkareem (2002). Human resource management practices in public and private primary schools in Ilorin metropolis of Kwara State, Nigeria Nigerian Journal of Guidance and Counselling http://www.ajol.info/index.php/njgc/article/view/36964.

Ayob Jantan. (2005). Pengetua sekolah yang efektif. Siri Penguruan Sekolah. Bentong: PTS Professional Publishing Sdn. Bhd. 
Azlin Norhaini Mansor. (2006). Amalan pengurusan Pengetua. Universiti Kebangsaan Malaysia.

Bazeley, P. (2007). Qualitative data analysis with NVivo. London: Sage.

Berliner, D. C. (2005). The near impossibility of testing for teacher quality. Journal of Teacher Education, 56(3), 205-213.

Biklen, S. K., \& Bogdon, R. C. (2007). Qualitative research for education: an introduction to theories and methods. United States of America: Pearson Education, Inc.

Blandford, Sonia. (2009). Mengurus sumber sekolah. Terj. Zahara Mohd Salleh. Kuala Lumpur: PTS Publication \& Distributors.

Braton J. \& Gold J. (1999). Human Resource Management Theory and Practice. London: Macmillan.

Bryman, A. (2008). Social research methods. New York: Oxford University Press Inc.

Chamberlin, R; Wragg, T; Haynes, G and Wragg, C (2002). 'Performance-related pay and the teaching profession: a review of the literature', Research Papers in Education, 17(1), 31-49.

Chanhorm, C., Chotisukan, S., and Gosalantagoon, O. (2011). Need to participate in Personnel administration of the Teacher in School under the Jurisdiction of Prachi Buri Educational Service Area. Journal of Graduate Studies Valaya Alongkorn Rajapat University, 1(Jan-April), 1-2.

Clincy, V. A. (2003). Software Development Productivity and Cycle Reduction, CCSC Eastern Conference - Consortium for Computing Sciences in Colleges, Dezembro, 2003.

Corral, C.R. (2009). An investigation of the relationship between performance appraisal and career development and advancement of mid-level women in student affairs administration. Unpublished doctoral dissertation, University Layola of Chicago.

Creswell, J. W. (2003). Research design: Qualitative, quantitative, and mixed methods approaches. Thousand Oaks, CA: Sage Publications.

Creswell, J.W. (2005). Educational research. New Jersey: Pearson Merrill, Prentice Hall.

Creswell, J. W. (2012). Planning, conducting, and evaluating quantitative and qualitative research $\left(4^{\text {th }}\right.$ edn. $)$. Thousand Oaks, CA: Sage Publications.

Cuming, M.W. (1980). The theory and practice of personnel management ( $4^{\text {th }}$ ed.) London: Heinemann.

Darling-Hammond, L. (2003). Keeping good teachers: Why it matters what leaders can do. Educational Leadership, 60(1), 6-13.

Dyer, L. (1985). Strategic human resource and planning, In K,M, Rowland \& G.R. Ferris (Eds). Research in personnel and human resources management (American Business Review, 2(1), 1-30. Greenwich, CT: JAI Press.

Educational Planning and Research Division. (2008). Education in Malaysia: A journey to excellent. Kuala Lumpur: Ampang Press.

Gambini, F. (2011). Leadership capacity for succession and sustainability in a familyowned private school (Order No. 3465438). Available from ProQuest Education Journals. (883387092). Retrieved from http://search.proquest.com.ezaccess.library.uitm.edu.my/docview/883387092?acco untid $=42518$.

Gary, D. (2010). "Personnel Management", Prentice Hall International Editions, New Jersey

Guskey, T. R., \& Sparks, D. (1996). Exploring the relationship between staff development and improvements in student learning. Journal of Staff Development, 17(4), 34-38.

Herzberg F. (1966).Work and the nature of man. New York: World. 
Hewton, E. (1998). School focused staff development; guidelines for staff development. Lewer: Falmer.

Hoerr, T (1998). 'A case for merit pay', Phi Delta Kappan, 80(4), 326-27.

Holt, M (2001) 'Performance Pay for Teachers: The Standards Movement's Last Stand?' Phil Delta Kappan, 83(4), 321-317.

Jamaliah Abdul Hamid \& Norhashimah Ismail. (2005). Penguruan dan Kepimpinan Pendidikan - Teori, Polisi dan Perlaksanaan. Serdang: Penerbit Universiti Putra Malaysia.

Jamilah Ahmad \& Yusof Boon (2011). Amalan Kepimpinan Sekolah Berprestasi Tinggi (SBT) Di Malaysia. Journal of Edupres, 1(2011), 323-335.

Johnson, B., \& Christensen, L. (2004). Educational research: Quantitative, qualitative, and mixed approaches ( $2^{\text {nd }}$ edn.). USA: Pearson Education, Inc.

King, N. (2004). Using templates in the thematic analysis of text. Essential guide to qualitative methods in organizational research. London: Sage Publisher.

Kinzy, D., \& Minter, D. (2008). The Dynamics of teacher Development: Negotiating where We Stand. Pedagogy, V, 8. N, 3. Retrieved July 5, 2011 from http://muse.jhu.edu/journals/ped /summary /v008/8.3.kinzy.html.

Kvale, Steinar (1998). Interviews-An Introduction to Qualitative Research Interviewing. Thousand Oaks: Sage.

Legge, K. (1989). “Human Resource Management - a critical analysis” in J. Storey (ed.) /New Perspectives on Human Resource Management. London: Routledge, 19-40.

Litchman, M. (2006). Qualitative research in education: a user's guide. California: Sage Publication Inc.

Merriam, S.B. (1998). Qualitative research and case study: application in education. San Francisco: Jossey-Bass.

Ministry of Education Malaysia. (2015). Educational policy. Retrieved from http://www.moe.gov.my.

Mohd Bakri Musa, (2003). An Education System Worthy of Malaysia. Kuala Lumpur: Strategic Information Research Development (SIRD).

Nazrol Hassan, (2000). Analysis of Effectiveness: An Analysis in Sekolah Menengah Sains Sultan Ahmad Shah, Pekan, Pahang Darul Makmur, Thesis (B.Ed.), Scudai, Johore, Universiti Teknologi Malaysia.

Nik Suryani, (2008). A practical guide to interviewing in educational research. Kuala Lumpur: International Islamic University Malaysia.

Odden, A \& Kelley, C (2002). Paying Teachers For What They Know And Do: New And Smarter Compensation Strategies To Improve Schools, $2^{\text {nd }}$ Edition, Corwin Press, California.

Omar Abdull Kareem, (2001). Pengetua: dinamika pengurusan sumber manusia di sekolah. Jurnal Pengurusan dan Kepimpinan Pendidikan, 11(2), 38-52.

Omardin Ashaari, (1996). Pengurusan Sekolah: suatu panduan lengkap. Kuala Lumpur: Utusan Publications \& Distributors Sdn. Bhd.

Patton, M.Q. (2002). Qualitative Research and Evaluation Methods. Thousand Oaks, CA: Sage Publications.

Petersen, K. D. (2002). Effective teacher hiring: A guide to getting the best. Alexandria, VA: Association of Supervision and Curriculum Development.

Ramirez, A (2001). 'How merit pay undermines education', Educational Leadership, 58(5), 16-20.

Rockoff, Jonah. (2004). "The Impact of Individual Teachers on Student Achievement: Evidence from Panel Data." American Economic Review 94:247-252. 
Rothman, R. (2005). Landing the "highly qualified teacher" How administrators can hire and keep the best. In C. Chauncey (Ed.), Recruiting, Retaining, and Supporting Highly Qualified Teachers (pp. 31-42). Cambridge: Harvard Education Press.

Rusmini $\mathrm{Ku}$ Ahmad. (2004). Keberkesanan sekolah. Seminar Nasional Pengurusan dan Kepimpinan Pendidikan Ke -2. 6 - 9 November.

Sabar, N. (2004). From heaven to reality through crisis: Novice teachers as migrants. Teaching and Teacher Education, 20, 145-161.

Salkind, N. J. (2009). Exploring research ( $9^{\text {th }}$ edn.). Upper Saddle River: Prentice Hall.

Sanders, W. L., \& Rivers, J. C. (1996). Cumulative and residual effects of teachers on future student academic achievement. Research Progress Report. Knoxville: University of Tennessee Value-Added Research and Assessment Center.

Scherff, L., \& Hahs-Vaughn, D. L. (2008). What we know about English language arts teachers: An analysis of the 1999-2000 SASS and 2000-2001 TFS databases. English Education, 40, 174-200.

School Management Division. (2011). Teacher placement management, PK01. Kuala Lumpur: Ministry of Education Malaysia.

Sekaran, U. \& Bougie, R. (2010). Research Methods for Business: A Skill Building Approach (5th ed.). West. Sussex, UK: John Wiley \& Sons Ltd.

Seyfarth, J. T. (2005). Human resources management for effective schools. Boston, MA: Pearson.

Shafritz, J. M., Ott, J. S., and Jang, Y. S. (2010). Human resource theory or the organizational behaviour perspective. In D. Tatom, D. Bush, \& R. Green (Eds.), Classics of organization theory ( $\mathrm{p} \% .145-192)$. Boston, MA: Wadsworth-Cengage.

Shoeb Ahmad (2011). New Dimensions in Human Resource Management. New Delhi. Discovery Publishing House Pvt. Ltd.

Siow Heng Loke, et al. (1999). Government and private secondary schools: a comparison of academic achievement and educational equity, (Laporan projek PIER) Fakulti Pendidikan, Univeristi Malaya, Kuala Lumpur.

Slavin, R.E. (2007). Educational research in age of accountability. United States of America: Pearson Education, Inc.

Stake, R.E. (2010). Qualitative Research: Studying How Things Work. New York, NY: Guilford Press.

Strauss, A.L, \& Corbin, J., (1990; 1998). Basics of Qualitative Research: Techniques and Procedures for developing Grounded Theory, Sage Publications Ltd, London.

Thompson, J., \& Kleiner, B. H. (2005). Effective Human Resource Management of School Districts. Management Research News, 28 (2/3), 43. Retrieved from http://www.emerlaldinsight.com/journals.htm?articleid=1502891.

Tim Simkins, Mike Coldwell, Paul Close and Anne Morgan. (2009). Outcomes of In school Leadership Development Work. Journal of Educational Management Administration \& Leadership 37(1), 29-50.

Tomlinson, H (2000). 'Proposals for Performance Related Pay in English Schools', School Leadership and Management, 20(3), 281-298.

Tucker-Lively, F. (2014). The relationship between human resource management practices and turnover intentions of mid-level administrators (Order No. 3581281). Available from ProQuest Dissertations \& Theses Global. (1551604554). Retrieved from http://search.proquest.com.ezaccess.library.uitm.edu.my/docview/1551604554?acc ountid $=42518$

Werner, J.M. \& R.L. Desimone (2012). Human Resource Development. $6^{\text {th }}$ Edn., SouthWestern Cengage Learnin. 
Wichenje, K. M., Simatwa, E. M. W., Okuom, H. A., and Kegode, E. A. (2012). Human resource management: challenges for head teachers in Public Secondary Schools in Kenya, a case study of Kakamega East District, 3(2), 159-171.

Williamson, A. L. (2008). The influence of sector on human resource management: A study of public, charter, and private schools (Order No. 3338665). Available from ProQuest Dissertations \& Theses Global. (304391656). Retrieved from http://search.proquest.com.ezaccess.library.uitm.edu.my/docview/304391656?acco untid $=42518$.

Woodward, R. (2009). The Organisation for Economic Co-operation and Development (OECD). Milton Park, Abingdon, Oxon: Routledge.

Zaidatol Akmaliah Lope Pihie dan Foo Say Fooi. (2007). Pengurusan dan Kepimpinan Pendidikan. Penerbit Universiti Putera Malaysia Serdang. 